\title{
The Telephone and Its Pioneers
}

This year, 1962, marks the 40th birthday of the Iowa Telephone Pioneers. The purpose of the organization, which has become increasingly more active, is well stated in its objectives:

The purpose of this chapter shall be to carry on Pioneer work within its territory in accordance with the purpose of the Association, which is: "to provide a means of friendly association for the longer-service employees in the telephone industry, both active and retired, and to promote among them a continuing fellowship and a spirit of mutual helpfulness; to exemplify and perpetuate those principles which have come to be regarded as the ideals and traditions of the industry; and to participate in such undertakings as may be deemed to make for the happiness, well-being and usefulness of the membership and for the progress of the Association."

The Iowa Pioneers stemmed, naturally, from a larger national group, the Telephone Pioneers of America, which celebrated its 50th anniversary last year. It started out as a sort of Bell System-wide organization of longer service telephone people. It was only after some years that the present plan of local and geographic sub-divisions developed.

The organization of the Telephone Pioneers of America took place on the 63rd birthday of Henry W. Pope whose idea it was to found this society. Pope was a pioneer in the early work of organizing the Bell System. He began work at the age of 14 in 1862, as telegraph operator and later manager for the American Telegraph Company in Massachusetts. During the early $1870^{\circ}$ s, he was in the telegraph business in New York City.

Mr. Pope became enthused about the possibilities of the telephone in 1877 and personally installed the first telephone in New York City. He promoted telephone companies in Cleveland, Pittsburgh and other localities. In 1879, he became General Superintendent of the Bell interests in the New York vicinity.

During the period 1882 to 1895 , Mr. Pope was busy promoting and building various railway and electric light plants. In 
1895 he returned to the telephone business and remained in it until his retirement in 1915. He was General Traffic Manager of the Southern Bell for some years and was General Manager of the Bell Company of Buffalo, New York during a period in which the plant was almost entirely rebuilt and greatly developed.

From written accounts of social activities in Company news bulletins and photographs of outings and picnics from various sources, it is apparent that telephone people have always enjoyed a friendly association. Recognition of these activities and the spirit that prompted them, suggested to Mr. Pope the idea of an organization of longer service employees.

Working with Charles R. Truex and Thomas B. Doolittle, $\mathrm{Mr}$. Pope perfected the idea of this new society which was to become the Telephone Pioneers of America. During 1910 Doolittle, Pope and Truex as a self-appointed organizing committee, circulated a membership paper among those they could reach personally and secured 169 names. Later they sent letters to all the prominent early telephone pioneers whose addresses they could obtain. Over 450 accepted the invitation to join, and on August 21, 1911, a call went out for a meeting of the society.

Two hundred and forty-five men attended that first meeting of the Telephone Pioneers of America at the Somerset Hotel in Boston on November 2 and 3, 1911. Their purpose in founding their new society as stated in the constitution was:

"For the purpose of recalling and perpetuating the facts, traditions and memories attaching to the early history of the telephone and the telephone system; preserving the names and records of the participants in the establishment and extension of this great system of electrical inter-communication; the promotion, renewal and continuance of the friendships made during the progress of the telephone industry between those interested therein; and the encouragement of such other meritorious objects consistent with the foregoing as may be desirable."

The early Pioneers lived up to this statement of purpose at their early meetings. The names of the speakers and those in attendance of those meetings reads like a list of the men 
who founded the telephone business. At the first meeting, President Theodore N. Vail of the A.T.\&T. Co. was elected the first Pioneer President and Mr. Pope was the first secretary. Alexander Graham Bell was present and told the story of the invention of the telephone.

Yearly meetings were held in New York, 1912; Chicago, 1913; Richmond, 1914; San Francisco, 1915, and Atlanta, 1916. Minutes of these meetings indicate that among the speakers were men who made important contributions to the telephone business, such as Thomas A. Watson who assisted Bell in developing the first telephone and Thomas $\mathrm{D}$. Lockwood who acted as general counsel on about 600 suits involving Bell patents.

During the years following the Boston meeting in 1911, many eligible employees became members of the Telephone Pioneers of America. The original service requirement for membership was 25 years. Later this was changed to 21 years or more of service in the telephone industry.

As the membership grew in size and extended throughout the United States and Canada, it became desirable to establish branches of the parent organization on a geographical basis. At the annual convention held in St. Louis in 1921 the constitution was revised to provide for Chapters in any locality, and the organization of a General Assembly, to be formed of delegates from the local chapters.

The first meeting under the new Constitution was held in Cleveland in 1922. Nineteen Chapters were represented with an attendance of 746 of whom 65 were delegates.

\section{The Story of Hawkeye Chapter No. 17}

During 1922 many chapters were organized throughout the Bell System. Hawkeye Chapter was organized in Iowa; its charter carried the date of September 12, 1922. The number 17 signifies it was the seventeenth chapter authorized. Wainman Chapter in Minnesota and North Dakota is identified as number 18 and Yost Chapter in Nebraska and South Dakota is number 19.

In 1926, the name of Hawkeye was changed to George E. McFarland Chapter No. 17 to honor a man who, after a distinguished telephone career of 30 years in Iowa, ended his 
45 years of telephone service in 1925 as Chairman of the Executive Committee of the Pacific Telephone \& Telegraph Company. In 1954, the chapter voted to change the name back to Hawkeye. The change was decided upon because there were no longer any active pioneers and only a few life members who had been personally acquainted with Mr. McFarland. Also the name Hawkeye was widely recognized throughout the Bell System and the country as symbolic of Iowa. Success of University of Iowa football teams during the 1950 's served to further identify the name of Hawkeye with the state of Iowa.

During the period 1922-1930, all Pioneer activities in Iowa were administered from Chapter headquarters in Des Moines. The chapter president appointed some person to act as chairman in each district to organize social activities which usually took the form of an annual picnic featuring a ham dinner. District Chairman appointed such assistants as were necessary to carry on the picnics of other social activities.

\section{Early Days of the Telephone}

Without the telephone, it is natural that this organization would not exist. This device, which most take for granted, developed quite interestingly from its birth to the present.

Alexander Graham Bell's telephone patent was granted March 7, 1876. A company was formed to manufacture telephones and to develop their use. The original telephone was a good receiver but a poor transmitter; however, more efficient transmitters and then signaling devices and switchboards were developed so that the telephone became a practical thing.

The first commercial telephone exchange was placed in service in January, 1878 at New Haven, Connecticut. It had eight lines and 21 telephones.

The powerful Western Union Telegraph Company recognized the telephone as a serious competitor, organized the Gold and Stock Telephone Company and entered the telephone field, using a transmitter invented by Thomas A. Edison. It built many exchanges.

The Bell Company claimed patent infringement and brought 


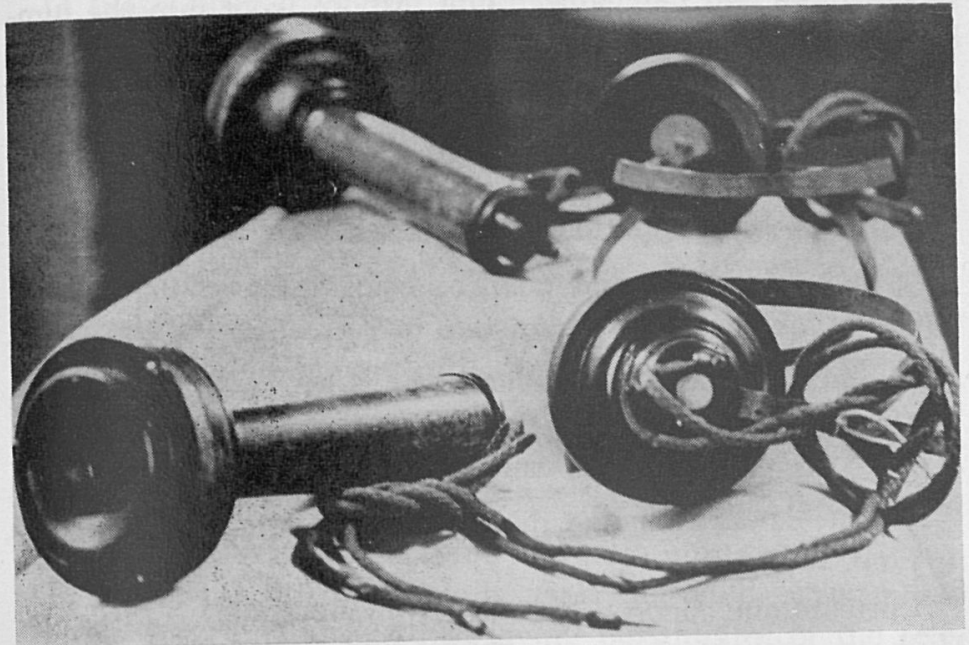

First telephone transmitter and receiver used in Iowa (1881).

suit. The Western Union settled with the Bell Company and agreed to retire from the telephone field in November, 1879. The Bell Company agreed to buy the telephones and exchanges which Western Union had built. This included 55 exchanges and 56,000 telephones. Four of these exchanges were in Iowa.

In April, 1880, the American Bell Telephone Company was organized and became an operating company with power to hold stock in other companies. In 1885, a subsidiary, the American Telephone and Telegraph Company, was organized to build and operate long-distance lines to interconnect the various regional Bell companies. In 1900, the American Telephone and Telegraph Company succeeded the American Bell as the parent company.

Much of the early use of the telephone was for private line service such as connecting homes with places of business, or hotels with railroad stations. Usually telephones for this private line service, as well as for exchange service, were rented from the parent Bell Company.

By 1879 there were a number of private lines in Iowa. In Dubuque a man named Moore had a line connecting his office and lumber yard. His son, A. A. Moore, went to Boston to 
secure these two telephones. A. A. Moore went into the lumber business in Marshalltown and was one of the organizers of the Marshalltown Telephone Company and was prominent in the independent telephone field in Iowa.

Another early private line was at Cedar Rapids connecting the store of H. C. Waites and Pope \& Billaus.

A. J. Barkley had a line connecting his office at Boone with the courthouse at Boonesboro two miles away.

The first commercial exchange in Iowa was opened by Western Union at Keokuk in 1878. Exchanges at Des Moines, Davenport, and Ottumwa were also built by Western Union.

The first Bell exchange in Iowa was opened in Dubuque in June, 1879.

A private line connecting F. M. Hubbell's office at Fifth and Mulberry with his home on Fifth north of Grand was built prior to the opening of an exchange in Des Moines.

The Davenport Gazette reported on February 21, 1880, that there were 96 telephones "in actual connection with the central office." Subscribers in Davenport had the privilege of talking to users in Rock Island and Moline "day and night."

The parent Bell Company licensed a number of companies to build in various parts of Iowa and at one time there were as many as 18 such licenses in the state. There were a few toll lines connecting some of the exchanges. The limit of commercial service was about 50 to 75 miles. Messages for longer distances were passed along by an operator at an intermediate point. The early toll lines were a single iron wire grounded and subject to cross talk and other electrical interference. One of the early toll lines was from Des Moines to Winterset. The Iowa State Register of November 5, 1882, reports the opening of the line and that service would be furnished free for one day and also "to accommodate all who desire to converse from their Des Moines homes to Winterset, little buoks costing $\$ 5$ and $\$ 10$ will be provided in the form of a 1,000 mile ticket; these must be left at the central office and a strip will be torn out for each 'talk'; which the owner has with Winterset. Parties without books will be required to go to the central office in this city to do their talking." 
In those early days, the building of Bell toll lines was financed in part by sale of such coupon books. Later in the $1890^{\circ} \mathrm{s}$, independent companies financed much toll line building in this way.

In 1893 there were three Bell companies in Iowa operating 60 exchanges and something less than 10,000 telephones.

With the expiration of the fundamental Bell patents in 1893 companies were formed to make independent telephones and switchboards and the era of competition started.

In the early days of independent telephony, a number of telegraph operators, doctors and druggists organized telephone companies. Telegraph operators were interested, of course, because they had some knowledge of electrical communication. Doctors probably became interested because they saw the time saving and life saving possibilities of the telephone. The interest of druggists probably came about as follows: when a toll line was run into a town without exchange service, it was desirable to have the toll station in a location which was open long hours. Frequently, the toll station was located in a drug store and the druggist would send a messenger for the called party. Sometimes a private line was installed to the home or office of frequently called patrons; thus, druggists had some appreciation of the needs for exchange service. Two of the charter members of Hawkeye Chapter who came into the telephone business as a result of such drugstore communications experiences were B. C. Way and H. G. Conger.

Independent telephone companies were organized by citizens with local capital, and exchanges were built most of the cities and towns where the Bell Company operated and in many towns which Bell had thought too small to support an exchange.

An era of vigorous competition followed, which continued for many years before the Bell and independent companies got together to eliminate dual service and other features which were irksome to the telephone using public.

(Courtesy Hawkeye Chapter, Iowa Telephone Pioneers and R. J. Fisher.) 
Copyright of Annals of Iowa is the property of State of Iowa, by \& through the State Historical Society of Iowa and its content may not be copied or emailed to multiple sites or posted to a listserv without the copyright holder's express written permission. However, users may print, download, or email articles for individual use. 